\title{
Use of Phage Display technology in development of canine visceral leishmaniasis vaccine using synthetic peptide trapped in sphingomyelin/ cholesterol liposomes
}

Christina Monerat Toledo-Machado ${ }^{1}$, Lilian Lacerda Bueno ${ }^{1}$, Daniel Menezes-Souza', Ricardo Andrez Machado-de-Avila ${ }^{3}$, Christophe Nguyen ${ }^{4}$, Claude Granier ${ }^{4}$, Daniella Castanheira Bartholomeu', Carlos Chávez-Olórtegui and Ricardo Toshio Fujiwara ${ }^{{ }^{*}}$

\begin{abstract}
Background: Leishmania parasites can cause visceral or cutaneous disease and are found in subtropical and tropical regions of the Old and New World. The pathology of the infection is determined by both host immune factors and species/strain differences of the parasite. Dogs represent the major reservoir of Leishmania infantum (syn. L. chagasi) and vaccines are considered the most cost-effective control tools for canine disease.

Methods: Selection of immunodominant peptides was performed by Phage Display to identify sequences recognized by L. infantum naturally infected animals. Sera from Leishmania infected animals were used in the biopanning to selection of specific peptides. Serum samples from T. cruzi infected and healthy animals were used as control. After selection, synthetic peptides were produced in membrane (spot-synthesis) in soluble form and blotting and ELISA were performed for validation of serum reactivity. Selected peptide was formulated with aluminum hydroxide and liposomes and immunization was performed in BALB/c mice. Protection was determined by qPCR after challenge infection with virulent $L$. infantum.

Results: We reported the selection of Peptide 5 through Phage Display technique and demonstrate its ability to promote a state of immunity against $L$. infantum infection in murine model after immunization using liposomes as vaccine carrier. Our results demonstrate that immunization with Peptide 5 when formulated with aluminum hydroxide and liposomes is immunogenic and elicited significant protection associated with the induction of mixed Th1/Th2 immune response against $L$. infantum infection.
\end{abstract}

Conclusion: Peptide 5 is a promising vaccine candidate and the findings obtained in the present study encourage canine trials to confirm the effectiveness of a vaccine against CVL.

Keywords: Phage Display, Canine Visceral Leishmaniasis, Vaccine, Synthetic Peptides, Liposomes

\footnotetext{
*Correspondence: fujiwara@icb.ufmg.br

'Departamento de Parasitologia, ICB, Universidade Federal de Minas Gerais,

CP: 486 - CEP: 31.270-901, Belo Horizonte, Minas Gerais, Brazil

Full list of author information is available at the end of the article
}

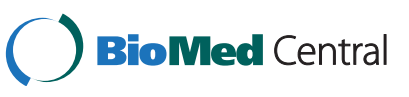

(c) 2015 Toledo-Machado et al.; licensee BioMed Central. This is an Open Access article distributed under the terms of the Creative Commons Attribution License (http://creativecommons.org/licenses/by/4.0), which permits unrestricted use, distribution, and reproduction in any medium, provided the original work is properly credited. The Creative Commons Public Domain Dedication waiver (http://creativecommons.org/publicdomain/zero/1.0/) applies to the data made available in this article, unless otherwise stated. 


\section{Background}

Canine visceral leishmaniasis (CVL), caused by Leishmania infantum, is a endemic disease and affects millions of dogs all over the world such as the Mediterranean basin, China, Latin America and is an emergent in North America [1,2]. Transmission between dogs, or from dogs to human occurs by the bite of a phlebotomine sand fly. Dogs are the main reservoir and responsible for maintaining the domestic cycle of parasites while stray dogs and wild canids maintain the peridomestic cycle [3,4]. Control of CVL is proposed to be central for limiting the endemic transmission cycle of this zoonotic disease [5,6]. There are evidences that Leishmania-infected dogs never achieve parasitological cure, and the widespread use of the available anti-Leishmania drugs for human and canine treatment may contribute to parasite drug resistance $[7,8]$.

Strategies to control CVL are still ineffective [9]. Vaccination has proven to be the most effective way to reduce mortality and morbidity caused by other infectious diseases in the history of humanity. The development of an effective vaccine in dogs would restrict the spread of the disease reducing infectivity to sand fly vectors and transmission to human beings $[10,11]$. Among the different approaches for vaccine development, Phage Display proved to be a successful technique due to fast identification of molecules that might be useful in the design of new immunotherapeutic agents and vaccines [12-14]. In the current work, we demonstrate that a selected peptide (Peptide 5) using Phage Display technique, when formulated with Aluminum Hydroxide and Cholesterol/Sphyngomielin liposomes, is highly immunogenic and presented a significant protective effect in murine model after challenge infection with virulent $L$. infantum. Taken together, our results show that Peptide 5 is a promising vaccine candidate and support CVL control.

\section{Methods}

Production of total L. infantum protein antigen (LiAg)

L. infantum (MHOM/BR/1975/BH46) were grown at $24^{\circ} \mathrm{C}$ in Schneider's medium (Sigma-Aldrich) supplemented with $10 \%$ fetal bovine serum (Cultilab, Brazil), $200 \mathrm{U} / \mathrm{mL}$ penicillin and $100 \mu \mathrm{g} / \mathrm{mL}$ streptomycin (all from Life Technologies, USA), $\mathrm{pH}$ 7.2. Total crude antigen of L. infantum ( $\mathrm{LiAg}$ ) was prepared from stationary phase promastigotes, submitted to 7 cycles of freezing (liquid nitrogen) and thawing $\left(42^{\circ} \mathrm{C}\right)$, followed by cell disruption by sonication (Ultrasonic processor, GEX600) with cycles of $10 \mathrm{sec}$ for $2 \mathrm{~min}$ at $35 \mathrm{MHz}$. The extracts were then submitted to centrifugation at $8,000 \mathrm{~g}, 20 \mathrm{~min}$ at $4^{\circ} \mathrm{C}$. Supernatant was collected and stored at $-80^{\circ} \mathrm{C}$ until further use. The protein concentration was estimated by the Bradford method [15].

\section{Preparation of antibodies for Biopanning}

Antibodies used for biopanning were purified from 38 sera from $L$. infantum naturally infected dogs. Infection was determined by a positive immunofluorescence (IFAT) titre at a 1:40 serum dilution, positive reactivity in ELISA and parasitological diagnosis of Leishmania in bone marrow or spleen samples. Antibodies from sera of 38 healthy dogs with negative IFAT and parasitological tests were included as negative controls. Fifteen serum samples of dogs experimentally infected with Trypanosoma cruzi parasite were also collected. Polyclonal IgGs from infected animals specific to LiAg were purified using ammonium sulfate precipitation and filtration through ProteinA-Sepharose-4B column [16]. Following elution and neutralization using $\mathrm{NaOH} 0.1 \mathrm{M}$, the IgG fraction was dialyzed with PBS and the protein concentration was determined by the Bradford method [15]. IgGs from negative controls and from T. cruzi infected dogs were also fractionated as described. IgG reactivity against LiAg was confirmed by ELISA.

\section{Ethics statement}

All sera samples used for biopanning were obtained from the Veterinary Hospital of the Federal University of Minas Gerais and the experiments were performed in compliance with the University's Animal Experimentation Ethic Committee (CETEA), protocol 122/2009. All sera were stored at $-20^{\circ} \mathrm{C}$ until use. Procedures related to immunization were also approved by CETEA (protocol 44/2012).

\section{Phage display experiments \\ Biopanning}

M13 phage libraries expressing 15-mer $\left(X_{15}\right)$ and 12-mer peptides $\left(X \mathrm{C} X_{8} \mathrm{CX}\right)$ were described by Bonnycastle et al. (1996) [17] and obtained from Dr. John Scott (British Columbia, Canada). Three cycles of biopanning were performed as described previously [18]. After three rounds of enrichment, individual phage clones were isolated and further analyzed.

\section{Screening}

ELISA plates (Becton Dickinson) were coated with $1 \mu \mathrm{g} /$ well of anti-LiAg IgGs or anti-T. cruzi IgGs in $100 \mathrm{mM}$ $\mathrm{NaHCO}_{3}, \mathrm{pH} 8.6$ and overnight at $4{ }^{\circ} \mathrm{C}$. Plates were washed with PBS, $0.1 \%$ Tween 20 and then blocked with PBS, $0.1 \%$ Tween $202 \%$ non-fat dried milk for $1 \mathrm{~h}$ at $37^{\circ} \mathrm{C} .10^{10}$ $\mathrm{TU}$ of individual phages isolated after third enrichment step and $50 \mu \mathrm{L}$ of blocking buffer was then added to each well. Phage particles were incubated for $2 \mathrm{~h}$ at $37^{\circ} \mathrm{C}$. Binding was detected using a peroxidase conjugated anti-M13 antibody (Roche) diluted 1:3000 in blocking buffer. After $1 \mathrm{~h}$ at $37^{\circ} \mathrm{C}$ and washing, the peroxidase substrate was added. Resulting color was measured at $492 \mathrm{~nm}$ with an 
automated microtiter plate reader (Bio-Rad, USA). Afterwards, twelve clones were selected and checked by ELISA for their ability to bind to anti T. cruzi dog IgG.

\section{Phage binding analysis by ELISA}

The clone selected with anti-LiAg antibodies was used in a new format-ELISA to verify their reactivity with sera samples of dogs with VL. Plate was sensitized with $10^{10}$ phages $/ \mathrm{mL}$ of individual clones or with $\mathrm{LiAg}(0.5 \mu \mathrm{g} / \mathrm{well})$ in coating buffer. The plate was washed and blocked as previously described and incubated with $100 \mu \mathrm{L}$ of sera samples of infected and healthy dogs, diluted 1:100, in PBS-Tween $20(0.05 \%)$ for $2 \mathrm{~h}$ at $37^{\circ} \mathrm{C}$. Binding was detected using a peroxidase conjugated anti-dog IgG antibody (Sigma-Aldrich) diluted 1:5,000 in blocking buffer. After $1 \mathrm{~h}$ at $37^{\circ} \mathrm{C}$ and washing, the peroxidase substrate was added and reaction was measured as previously described.

\section{DNA sequencing, synthesis, chromatography and mass spectrometry of soluble peptides}

Approximately $9 \mu \mathrm{g}$ of single-stranded DNA was purified using the QIA prep Spin M13 protocol (Qiagen). Sequencing reactions were carried out according to the dideoxy chain termination method [19], using the ABI Prism Kit (Applied Biosystems) for the automatic method with ABI PRISM 377 (PerkinElmer). The primer reverse 5'-TCGGCAAGCTCTTTTAGG-3' was used for sequencing. The sequence obtained was translated.

\section{Peptides synthesis on cellulose membrane}

Peptide selected for immunization and a non-related peptide were synthesized on a cellulose membrane, as previously described by Laune et al. (2002) [20]. Membranes were obtained from INTAVIS (Koln). An ASP222 robot (Intavis) was used for the coupling steps. Peptide was acetylated at the $\mathrm{N}$-terminus. After the peptides sequences had been assembled, the side-chain protecting groups were removed by trifluoroacetic acid treatment [21]. After peptide synthesis on cellulose membrane, ELISA-Spot was performed. Membranes were washed 3 times with TBS (Saline, KCl $0.002 \mathrm{M}$, Tris $0.05 \mathrm{M}$ ) $\mathrm{pH} 7.4$ and blocking solution was added (casein 0.5\% and T-TBS $0.05 \%$ ). After sixty minutes, membranes were incubated with positive and negative canine serum pool 1:100. After $1 \mathrm{~h}$ at $37^{\circ} \mathrm{C}$ and washing, the anti-dog peroxidase conjugate was added. After incubation for 30 min with substrate (MTT-BCIP), membranes were analyzed according to the resulting color.

\section{Synthesis of soluble peptide}

Soluble peptides were synthesized in ResPep SL Synthesizer by Fmoc chemistry [22]. After synthesis the peptides were desprotected and released from the resin by trifluoroacetic acid treatment in the presence of the appropriate scavengers. The peptide was lyophilized and their purity assessed by HPLC and their mass confirmed by mass spectrometry according to Machado-de-Avila et al. (2011) [23].

\section{Preparation of liposomes containing peptide}

Immunogens (selected peptide - Peptide 5 or LiAg) and PBS (as control) were encapsulated in liposomes, which were used as vaccine carrier. Sphingomyelin/Cholesterol multilamellar liposomes (ratio of 2:1) were prepared by dissolving $25 \mathrm{mg}$ of sphingomyelin (Sigma-Aldrich) and $6.5 \mathrm{mg}$ cholesterol (Sigma-Aldrich) in $20 \mathrm{ml}$ chloroform together with traces of methanol. The solution was kept in a 1,000-ml round-bottom flask and the solvent was removed by flash evaporation on a rotary evaporator at $37^{\circ} \mathrm{C}$. After drying under reduced pressure for $80 \mathrm{~min}$, the aqueous phase containing $2.1 \mathrm{mg}$ of immunogens in PBS, pH 7.4 was added to the flask. The lipid film was dislodged from the glass by the use of a vortex mixer. The liposomes were retrieved using a Pasteur pipette and then treated with ultrasonic vibration three times during 20s each. The liposome suspension was centrifuged at $8,000 \mathrm{~g}$ for $10 \mathrm{~min}$ at $4^{\circ} \mathrm{C}$ to remove nonencapsulated immunogens and the supernatant protein concentration was estimated by spectrophotometry. The encapsulation efficiency for the formulations was $85 \%$. The pelleted liposomes were resuspended and washed three more times with PBS by centrifugation and $0.5 \mathrm{mg}$ Aluminum Hydroxide was added $(200 \mu \mathrm{g} /$ animal). The compound was stored in PBS at $4{ }^{\circ} \mathrm{C}$.

\section{Immunization of Balb/c with Peptide 5 formulated into liposomes}

Mice were divided into 3 groups (18 mice/group). Each group was intraperitoneally immunized (Day 0) as follows: group I, liposomes that entrap the selected peptide (Peptide 5) $(50 \mu \mathrm{g} / 100 \mu \mathrm{L}$, intraperitoneal); group II, liposomes that entrap LiAg (50 $\mu$ g protein $/ 100 \mu \mathrm{L}$ intraperitoneal); group III, liposomes that entrap PBS (100 $\mu \mathrm{L}$, intraperitoneal). On Day 15, mice were boosted with the same immunogen at an equivalent dose. Mice were again immunized on days $22,29,36$ and 43 . Two weeks after last immunization (dasy 58), nine mice of each group were euthanized and spleens were harvested for cytokine measurements. Challenge infection on remaining animals ( 9 per group) was performed seven days after last immunization (day 65). Mice were inoculated intraperitoneally with $1 \times 10^{6} \mathrm{~L}$. infantum stationary promastigotes and after 4 weeks the parasite burden was determined by qPCR. Mouse $\beta$-actin gene (F: CAGAGCAAGAGAGGTATCC; R: TCATTGTAGAAG GTGTGGTGC) was used as internal control in order to confirm DNA integrity and to verify qPCR inhibitors 
(data not showed). In this step, $\beta$-actin qPCR was performed in parallel for each sample. As additional controls, five non-immune animals were also infected.

\section{Evaluation of immunogenicity induced by vaccination}

Antibody production was determined by indirect ELISA. Briefly, ELISA plates (Becton Dickinson) were coated with $2 \mu \mathrm{g} /$ well of Peptide 5 or $\operatorname{LiAg}(0.5 \mu \mathrm{g} /$ well $)$ in PBS and further blocked with PBS with $0.1 \%$ Tween 20 and $5 \% \mathrm{BSA}$ at $37^{\circ} \mathrm{C}$. After $1 \mathrm{~h} \mathrm{pool}$ of serum were serially diluted up to $10^{7}$. Binding was detected using a peroxidase conjugated anti-mouse antibody (Roche) diluted 1:5,000 in incubation buffer. After $1 \mathrm{~h}$ at $37^{\circ} \mathrm{C}$ and washing, the peroxidase substrate was added. The resulting color was measured at $492 \mathrm{~nm}$ with an automated microtiter plate reader (Bio-Rad). Endpoint titers were assigned by taking the lowest dilution with an OD that was higher than the negative control plus 0.100 [24].

In order to evaluate cellular response, spleen samples were obtained from immunized animals. Splenocytes were resuspended in RPMI 1640 containing 10\% FBS (Sigma-Aldrich) and seeded at $1 \times 10^{6} / \mathrm{mL}$ in 48 -well flatbottom plates (Nunc). The spleen cells were stimulated in vitro with either Pep 5 (10 $\mu \mathrm{g} /$ well $)$ or LiAg $(1 \mu \mathrm{g} /$ well $)$ or PHA $(25 \mu \mathrm{g} / \mathrm{mL})$ as a positive control for viability and cytokine production, and incubated at $37^{\circ} \mathrm{C}$ in $5 \% \mathrm{CO}_{2}$ for $48 \mathrm{~h}$ and then the supernatants were collected. The level of IL-10, IFN- $\gamma$, TNF- $\alpha$ and IL- 4 were determined by sandwich ELISA kit according to the manufacturer's instructions ( $R \& D$ systems). Cytokine concentrations were calculated from the standard curve using 5-parameter curve fitting software (SOFTmax Pro 5.3, Molecular Devices).

\section{Extraction of DNA and evaluation of spleen parasite load} by qPCR

DNA was extracted from the spleen samples using NucleoSpin ${ }^{\circ}$ Tissue (Macherey-Nagel) according to the manufacturer's instructions. The parasite load was calculated by qPCR according to a method described elsewhere $[25,26]$ with minor modifications. The parasite burdens were estimated using the following primers: Forward, 5'-TGTCGCTTGCAGACCAGATG-3' and Reverse, 5'-GCATCGCAGGTGTGAGCAC-3'. These primers amplified a 90 bp fragment of a single-copy-number $L$. infantum DNA polymerase gene (GenBank: AF009147). PCR was carried out in a final volume of $10 \mu \mathrm{L}$ containing 2 pmol of each DNA polymerase primers, SYBR ${ }^{\circ}$ Green (Applied Biosystems), $4 \mu \mathrm{L}$ of DNA with a concentration of $5 \mathrm{ng} / \mu \mathrm{L}$ and enough volume of ultrapure water. Reactions were processed and analyzed in an ABI Prism 7500 Sequence Detection System (Applied Biosystems). The following steps were programmed: $95^{\circ} \mathrm{C}$ for $10 \mathrm{~min}$ followed by 40 cycles at $95^{\circ} \mathrm{C}$ for $15 \mathrm{~s}$ and $60^{\circ} \mathrm{C}$ for $1 \mathrm{~min}$. Parasite quantification for each spleen sample was calculated by interpolation from the standard curve included in the same run, performed in duplicate, and expressed as the number of parasites per $20 \mathrm{ng}$ total DNA.

\section{Statistical analysis}

GraphPad Prism 5 (GraphPad Inc., USA) was used for statistical analysis. The Kolmogorov-Smirnov test was used to verify data distribution and Grubb's test was used to detect the outliers in the samples. Mean values of normally distributed data were compared using oneway analysis of variance (ANOVA) and P-values were assessed using Tukey's post-hoc analysis. Differences of $\mathrm{P}<0.05$ were considered significant.

\section{Results}

Phage reactivity by ELISA and mimotope peptide synthesis

In order to identify peptides that bind to anti-LiAg antibodies, four different phage libraries were screened. A significant enrichment of phage binding to the target antibodies was obtained after three rounds of panning. One hundred and ninety-eight phage clones were randomly picked from the third round of selection, and twelve clones were selected based on their reactivity (absorbance at $492 \mathrm{~nm} \geq 1.0$ ) against IgGs from L. infantum infected dogs. Afterwards, twelve clones were checked by ELISA for their ability to bind to anti-T. cruzi dog IgGs. Clone 5 (originating the Peptide 5) was further selected due to the highest reactivity against Leishmaniaspecific IgGs and any cross-reactivity with IgGs from dogs with Chagas disease (data not shown). Figure 1 shows the reactivity of sera samples of dogs with $\mathrm{VL}$

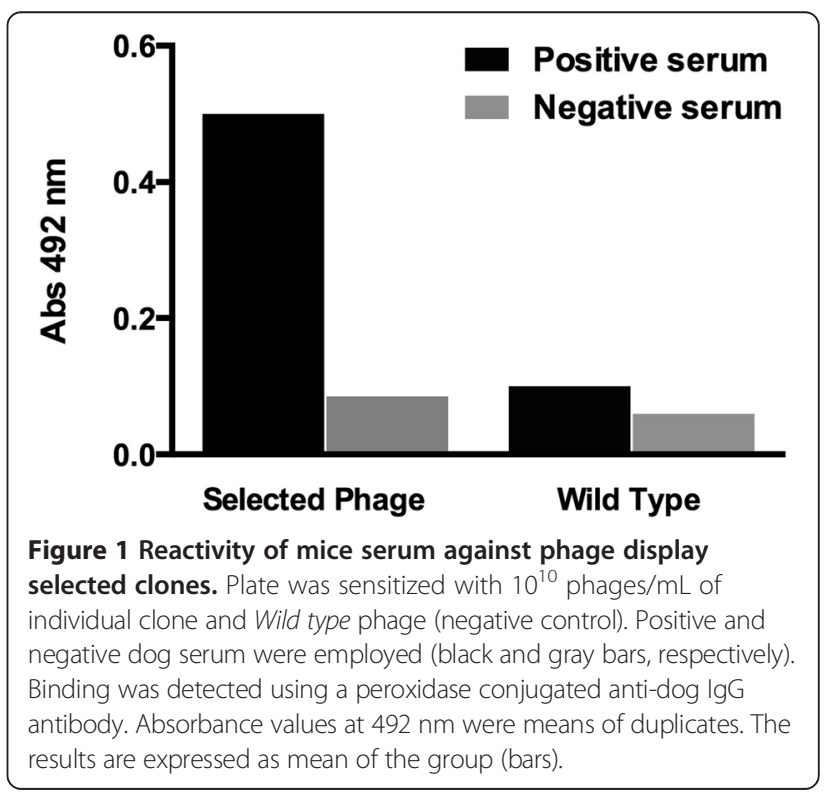


when the individual clone (Peptide 5) was used to sensitize the ELISA plates.

The DNA sequence of clone 5 was translated and the amino acid sequence of the peptide was deduced (ICARQDPAGNCS). The corresponding synthetic peptide was chemically synthesized, purified by reverse phase chromatography and its correct molecular weights were confirmed by mass spectrometry.

\section{ELISA-Spot assay}

Peptide 5 (corresponding to the sequence ICARQDPAGNCS) and a non-related peptide were synthesized on cellulose membrane by spot-synthesis. Figure 2 shows the specific reactivity of serum, demonstrating the recognition when samples from L. infantum infected animals were used.

\section{ELISA after cycles of immunization}

One week after last immunization, antibody levels in mice serum were analyzed by Indirect ELISA. Figure 3 shows absorbance values in animals immunized with Peptide 5, LiAg and PBS. Vaccination with Peptide 5 and LiAg elicited significant antigen-specific IgG responses compared to PBS. Antibodies titers were 1:400,000 (Peptide 5 group/Vac) and 1:100,000 (LiAg group/Ag).

\section{Cytokines production assay}

We determined whether immunization with Peptide 5 resulted in increased IFN- $\gamma$ or IL-10 production in response to LiAg stimulation. As shown in Figure 4, PBMC from mice vaccinated with peptide 5 , before infection, secreted significantly higher levels of IFN- $\gamma$ when stimulated with LiAg than PBMC collected from

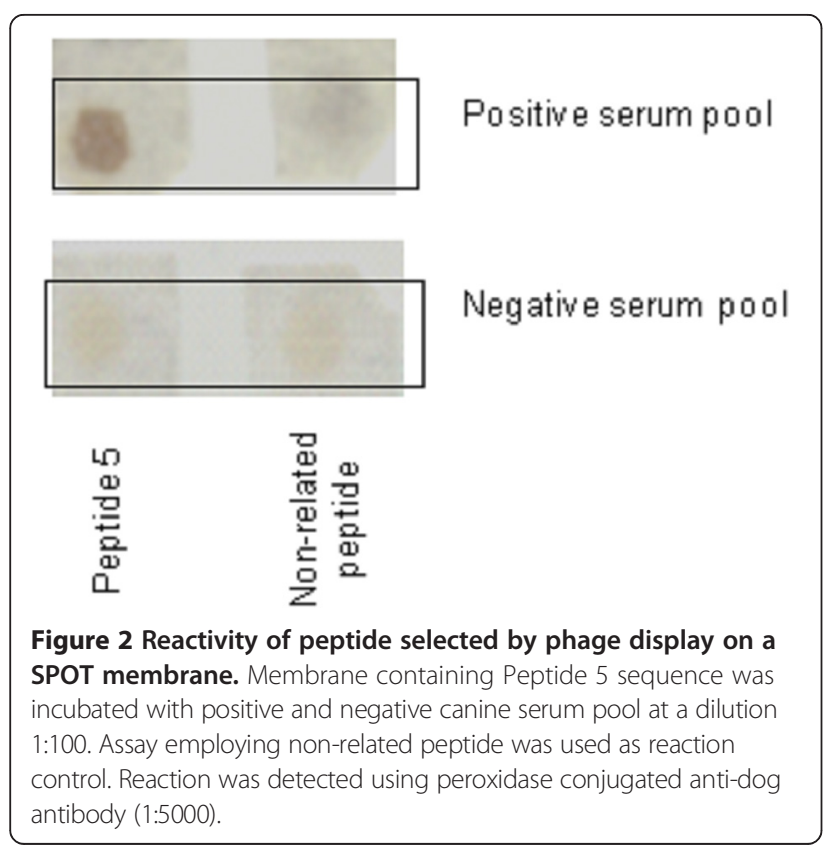

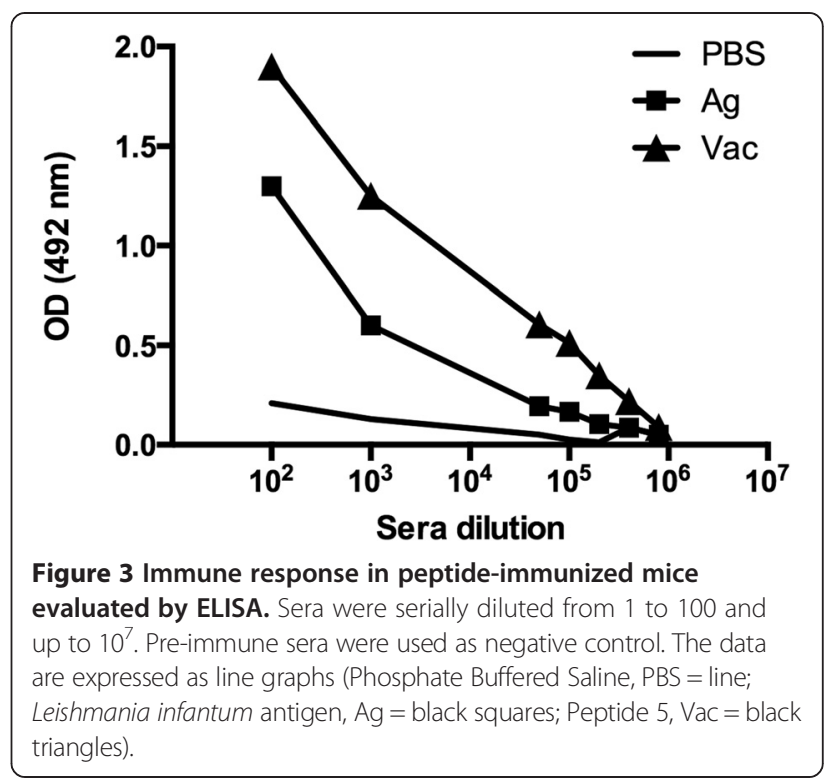

control infected mice. Additionally, the production of IL-10 was not significantly higher in the vaccinated mice as compared to control animals. No cytokine production was observed when cells were stimulated with Peptide 5 alone.

\section{Parasite load by quantitative PCR}

Parasite quantification was performed using DNA extracted from the spleen samples of mice from Peptide 5, LiAg and control groups. Animals immunized with Peptide 5 presented significant reduction of parasite burden (up to 98\%), when compared to control and LiAg groups (Figure 5). Peptide 5 demonstrated an excellent effectiveness as vaccine antigen.

\section{Discussion}

Development of a protective vaccine in dogs is the best strategy to efficiently control CVL, promoting a possible reduction of infectivity to sand fly vectors and, consequently, the transmission to humans [27]. A practical vaccine for use should be safe, inexpensive and elicit long-lasting immunity [28]. The use of synthetic peptides in vaccine field is promising [29]; when compared to the production of whole proteins, peptides are simpler to synthesize and are cheaper to produce [30]. The success of a vaccine depends on our current understanding of the characteristics of an effective anti-Leishmania immune response, as they have been already determined from human and murine studies [31,32].

In the present work, the selection of a leishmanial immunodominant epitope was performed by Phage Display technique. Sequence analysis in the GenBank databases did not reveal any significant similarity to the amino acid sequence of antigens previously characterized from 

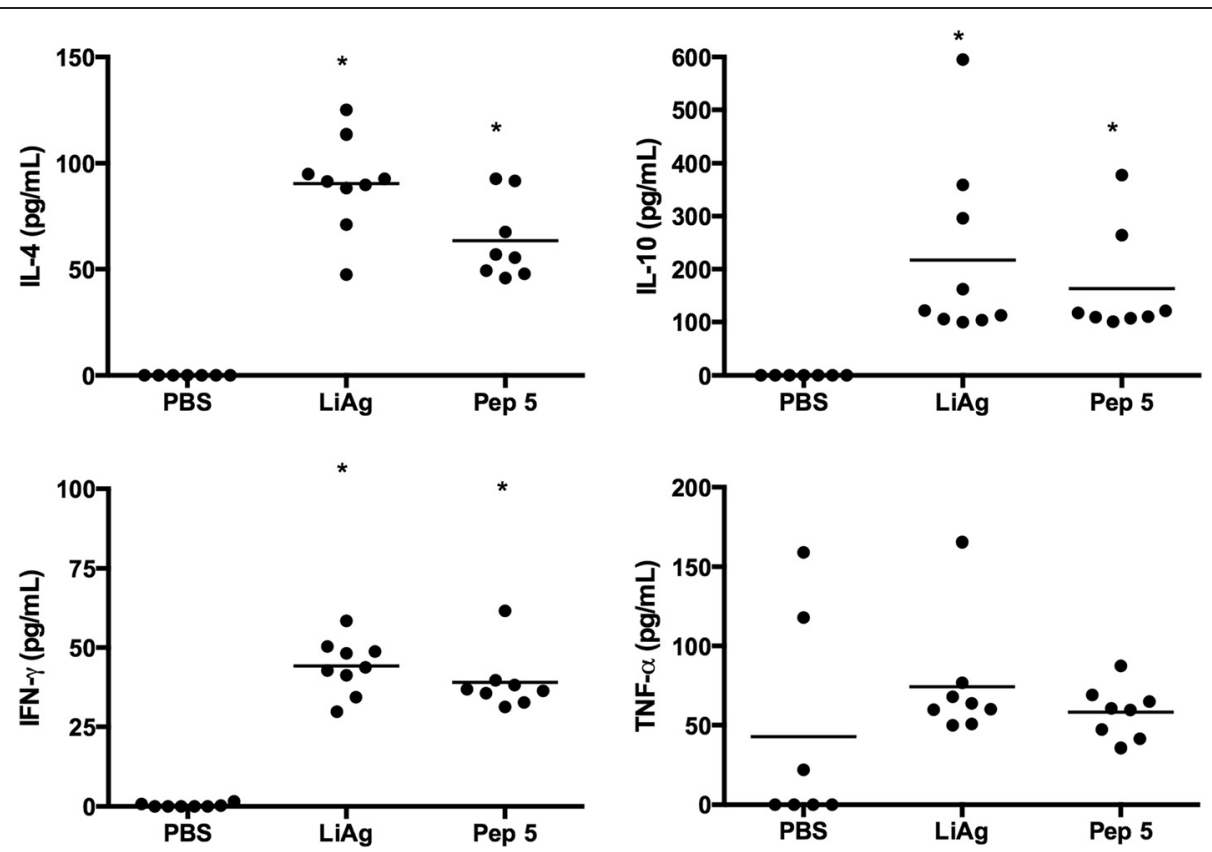

Figure 4 Cytokine levels detected in culture supernatants of murine PBMC. Levels of IFN- $\gamma$, TNF- $a$, IL-10 and IL-4 detected in PBMC culture supernatants of three groups (PBS, LiAg and Pep 5) produced in response to LiAg stimulation. The results are expressed as scattering of individual values (black circles) and mean of that group (line). Statistically significant differences in the parasite load between experimental groups are showed in the graph by "**" symbol.

Leishmania, suggesting this sequence corresponds to either unknown proteins or to mimotopes (conformational epitopes of Leishmania proteins). Furthermore, we demonstrated that immunization of mice with peptide 5 formulated with aluminum hydroxide and liposomes

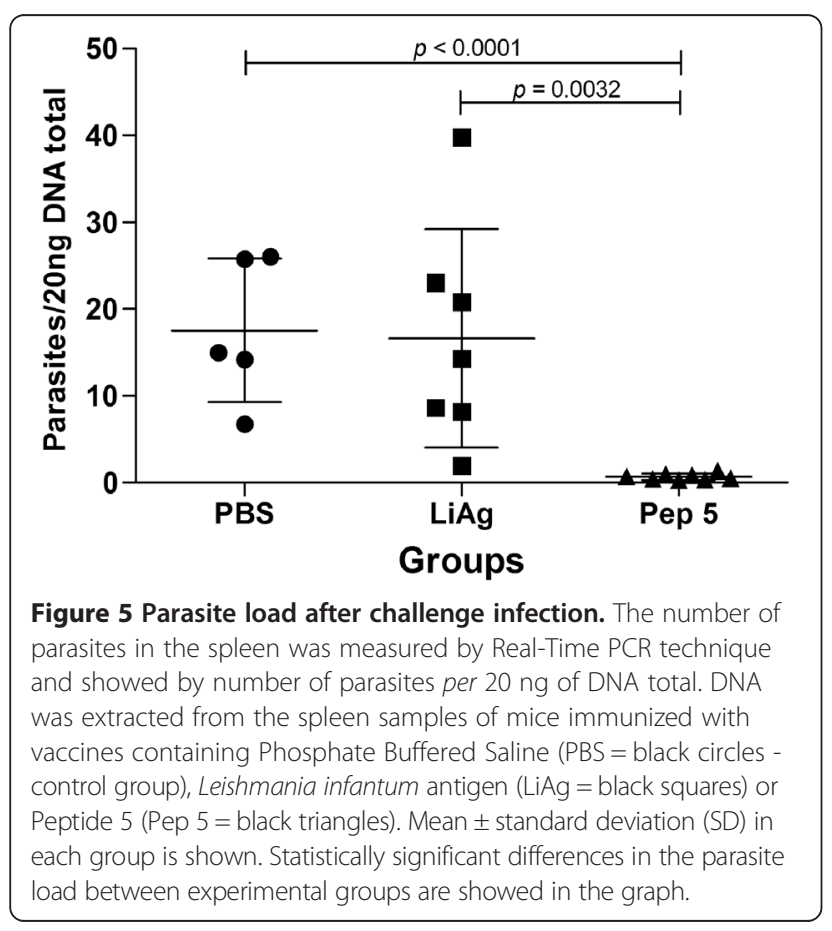

rendered high levels of antibodies, suggesting the immunogenicity was conferred by combined delivery technique and formulation with adjuvants, as immunogenicity might be improved after appropriate use of adjuvants [33]. The use of a proper adjuvant constitutes an important aspect in obtaining an efficient protocol of immunization [27]. Since the 1970s, it has been known that liposomal presentation of antigens can confer greater immunogenicity when compared to antigen alone $[34,35]$. Some advantages of liposomal vaccines are an opportunity for dose-sparing of antigen, plasticity with regard to lipid composition and recruitment of various components of the immune system [36,37]. In addition, liposomes also provide a physical means for either delivering encapsulated antigens or presenting surface-associated antigens with the ability to modulate epitope density and homogeneity.

Our findings demonstrated that experimental vaccine formulation (Peptide 5, liposome and Aluminum Hydroxide) achieved high levels of protection and produced a mixed Th1/Th2 response in mice. Briefly, resistance to leishmaniasis has been associated with a predominant IFN- $\gamma$ production from the antigen-specific CD4+ T lymphocyte population-termed $\mathrm{T}$ helper 1 (Th1) immune response [38]. These cells might be then effective in promoting macrophage activation at the site of the lesion, and the intracellular Leishmania are killed in a nitric oxide-dependent manner. Interestingly, while the protection conferred by Peptide 5 was significantly 
higher than observed in animals immunized with crude leishmanial antigen, the cytokine profile induced by immunization was similar in both groups. These data suggest that achievement of protection against $L$. infantum might also depend on other factors rather than solely in the cytokine production.

Concerning the vaccine formulation, Aluminumcontaining adjuvants are often used in vaccines against infectious diseases and in preparations for allergy immunotherapy $[39,40]$. However, they selectively stimulate a Th2 immune response in mice and a mixed response in human beings [41]. On the other hand, adsorption of antigens to aluminum adjuvants enhances the immune response by increasing phagocytosis and slowing the diffusion of antigens from the injection site, which allows larger time for inflammatory cells. The adsorptive strength is important as high affinity interactions interfere with the immune response. Adsorption is also associated to the physical and chemical stability of antigens [42-44].

While the use of vaccine using Peptide 5 trapped in sphingomyelin/cholesterol liposomes conferred a considerable degree of protection in the employed experimental model it is not clear whether protection is associated with long-term immunity considering the time between immunizations and challenge infection. Further studies are required to determine the profile of memory responses and extent of immunogenicity after immunization process. However, despite the possibility that vaccination with Peptide 5 might induce extrafollicular reaction (thus generating short-lived B cells) [45] or production/expansion of effector T cells [46] - highly effective against the pathogen but with limit duration of immunity, the use of such formulation may be considered as a component of future multivalent vaccines due to a high degree of protection even a few days after immunization. Moreover, further studies are also required to describe the impact of different adjuvants regardless of the evidence that liposomes represent an improvement of vaccine formulation [47]. Promising findings obtained in the present study encourage canine trials to confirm the effectiveness of a vaccine against CVL, which will control and reduce the chances of infectivity to sand fly vectors and consequently the transmission to dogs and humans.

\section{Conclusions}

Taken together our findings demonstrated that immunization with vaccine using the synthetic peptide 5 trapped in sphingomyelin/cholesterol liposomes achieved high levels of protection against visceral leishmaniasis and elicited a mixed Th1/Th2 response in mice. These results encourage its further use in canine trials to confirm the effectiveness of a vaccine against CVL.
Competing interests

The authors declare that they have no competing interests.

\section{Authors' contributions}

Conceived and designed the experiments: CMTM CCO DCB RTF. Performed the experiments: CMTM LLB DMS RAMA CN CG. Analyzed the data: CMTM LLB RAMA CCO RTF. Contributed reagents/materials/analysis tools: CN CG DCB CCO RTF. Wrote the paper: CMTM LLB DCB CCO RTF. All authors read and approved the final version of the manuscript.

\section{Acknowledgement}

This work was financially supported by the Brazilian National Research Council (CNPq), the Fundação de Amparo à Pesquisa do Estado de Minas Gerais/FAPEMIG, Pró-Reitoria de Pesquisa of Universidade Federal de Minas Gerais. CMTM was supported by a post doctoral fellowship from CNPq. DCB, CCO and RTF are supported by CNPq fellowships.

\section{Author details}

${ }^{1}$ Departamento de Parasitologia, ICB, Universidade Federal de Minas Gerais, CP: 486 - CEP: 31.270-901, Belo Horizonte, Minas Gerais, Brazil.

${ }^{2}$ Departamento Bioquímica e Imunologia, ICB, Universidade Federal de Minas Gerais, CP: 486 - CEP: 31.270-901, Belo Horizonte, Minas Gerais, Brazil.

${ }^{3}$ Unidade Acadêmica de Ciências da Saúde, Universidade do Extremo Sul Catarinense - CEP: 88.806-000, Criciúma, Santa Catarina, Brazil. ${ }^{4}$ SysDiag CNRS-BioRad UMR 3145, Cap Delta/Parc Euromédecine, 1682 rue de la Valsière, CS 61003, 34184 Montpellier Cedex 4, France.

Received: 25 September 2014 Accepted: 17 February 2015

Published online: 28 February 2015

\section{References}

1. Grimaldi Jr G, Tesh RB, McMahon-Pratt D. A review of the geographic distribution and epidemiology of leishmaniasis in the New World. Am J Trop Med Hyg. 1989;41(6):687-725.

2. Grimaldi Jr G, Tesh RB. Leishmaniases of the New World: current concepts and implications for future research. Clin Microbiol Rev. 1993;6(3):230-50.

3. Moreno J, Alvar J. Canine leishmaniasis: epidemiological risk and the experimental model. Trends Parasitol. 2002;18(9):399-405.

4. Cabrera OL, Munstermann LE, Cardenas R, Ferro C. PCR as a tool in confirming the experimental transmission of Leishmania chagasi to hamsters by Lutzomyia longipalpis (Diptera:Psychodidae). Biomedica: revista del Instituto Nacional de Salud. 2003;23(2):239-44.

5. Gradoni L, Maroli M, Gramiccia M, Mancianti F. Leishmania infantum infection rates in Phlebotomus perniciosus fed on naturally infected dogs under antimonial treatment. Med Vet Entomol. 1987;1(4):339-42.

6. Guarga JL, Moreno J, Lucientes J, Gracia MJ, Peribanez MA, Alvar J, et al. Canine leishmaniasis transmission: higher infectivity amongst naturally infected dogs to sand flies is associated with lower proportions of Thelper cells. Res Vet Sci. 2000;69(3):249-53.

7. Madeira M, Barbosa-Santos E, Marzochi M. Experimental infection of canine peritoneal macrophages with visceral and dermotropic Leishmania strains. Mem Inst Oswaldo Cruz. 1999;94(5):645-8.

8. Marzochi MC, Coutinho SG, De Souza WJ, De Toledo LM, Grimaldi Junior G, Momen $\mathrm{H}$, et al. Canine visceral leishmaniasis in Rio de Janeiro, Brazil. Clinical, parasitological, therapeutical and epidemiological findings (1977-1983). Mem Inst Oswaldo Cruz. 1985;80(3):349-57.

9. Madeira MF, Schubach A, Schubach TM, Pacheco RS, Oliveira FS, Pereira SA, et al. Mixed infection with Leishmania (Viannia) braziliensis and Leishmania (Leishmania) chagasi in a naturally infected dog from Rio de Janeiro, Brazil. Trans R Soc Trop Med Hyg. 2006;100(5):442-5.

10. Parra LE, Borja-Cabrera GP, Santos FN, Souza LO, Palatnik-de-Sousa CB, Menz I. Safety trial using the Leishmune vaccine against canine visceral leishmaniasis in Brazil. Vaccine. 2007;25(12):2180-6.

11. Fernandes AP, Costa MM, Coelho EA, Michalick MS, de Freitas E, Melo MN, et al. Protective immunity against challenge with Leishmania (Leishmania) chagasi in beagle dogs vaccinated with recombinant A2 protein. Vaccine. 2008;26(46):5888-95.

12. Manoutcharian K, Diaz-Orea A, Gevorkian G, Fragoso G, Acero G, Gonzalez E, et al. Recombinant bacteriophage-based multiepitope vaccine against Taenia solium pig cysticercosis. Vet Immunol Immunopathol. 2004;99(1-2):11-24. 
13. Lanzillotti R, Coetzer TL. Phage display: a useful tool for malaria research? Trends Parasitol. 2008;24(1):18-23.

14. Hell RC, Amim P, de Andrade HM, de Avila RA, Felicori L, Oliveira AG, et al. Immunodiagnosis of human neurocysticercosis using a synthetic peptide selected by phage-display. Clin Immunol. 2009;131(1):129-38.

15. Bradford MM. A rapid and sensitive method for the quantitation of microgram quantities of protein utilizing the principle of protein-dye binding. Anal Biochem. 1976;72:248-54.

16. Ey PL, Prowse SJ, Jenkin CR. Isolation of pure $\lg G 1$, IgG2a and $\lg G 2 \mathrm{~b}$ immunoglobulins from mouse serum using protein A-sepharose. Immunochemistry. 1978;15(7):429-36.

17. Bonnycastle LL, Mehroke JS, Rashed M, Gong X, Scott JK. Probing the basis of antibody reactivity with a panel of constrained peptide libraries displayed by filamentous phage. J Mol Biol. 1996;258(5):747-62.

18. Ferrieres G, Villard S, Pugniere M, Mani JC, Navarro-Teulon I, Rharbaoui F, et al. Affinity for the cognate monoclonal antibody of synthetic peptides derived from selection by phage display. Role of sequences flanking the binding motif. Eur J Biochem/FEBS. 2000;267(6):1819-29.

19. Sanger F, Nicklen S, Coulson AR. DNA sequencing with chain-terminating inhibitors. Proc Natl Acad Sci U S A. 1977;74(12):5463-7.

20. Laune D, Molina F, Ferrieres G, Villard S, Bes C, Rieunier F, et al. Application of the Spot method to the identification of peptides and amino acids from the antibody paratope that contribute to antigen binding. J Immunol Methods. 2002;267(1):53-70.

21. Frank D, Harland RM. Localized expression of a Xenopus POU gene depends on cell-autonomous transcriptional activation and inductiondependent inactivation. Development. 1992;115(2):439-48.

22. Gausepohl H, Boulin C, Kraft M, Frank RW. Automated multiple peptide synthesis. Pept Res. 1992;5(6):315-20.

23. de Machado Avila RA, Stransky S, Velloso M, Castanheira P, Schneider FS,

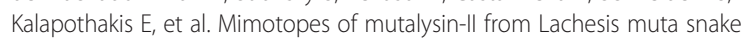
venom induce hemorrhage inhibitory antibodies upon vaccination of rabbits. Peptides. 2011;32(8):1640-6.

24. Bethony JM, Simon G, Diemert DJ, Parenti D, Desrosiers A, Schuck S, et al. Randomized, placebo-controlled, double-blind trial of the Na-ASP-2 hookworm vaccine in unexposed adults. Vaccine. 2008;26(19):2408-17.

25. Alves CF, de Amorim IF, Moura EP, Ribeiro RR, Michalick MS, Kalapothakis E, et al. Expression of IFN-gamma, TNF-alpha, IL-10 and TGF-beta in lymph nodes associates with parasite load and clinical form of disease in dogs naturally infected with Leishmania (Leishmania) chagasi. Vet Immunol Immunopathol. 2009;128(4):349-58.

26. de Almeida FS, Leite RS, Ituassu LT, Almeida GG, Souza DM, Fujiwara RT, et al. Canine skin and conjunctival swab samples for the detection and quantification of Leishmania infantum DNA in an endemic urban area in Brazil. PLoS Negl Trop Dis. 2012;6(4):e1596.

27. Alvar J, Bashaye S, Argaw D, Cruz I, Aparicio P, Kassa A, et al. Kala-azar outbreak in Libo Kemkem, Ethiopia: epidemiologic and parasitologic assessment. Am J Trop Med Hyg. 2007;77(2):275-82.

28. Reed C, Meltzer MI, Finelli L, Fiore A. Public health impact of including two lineages of influenza B in a quadrivalent seasonal influenza vaccine. Vaccine. 2012;30(11):1993-8

29. Noya O, Patarroyo ME, Guzman F, de Alarcon NB. Immunodiagnosis of parasitic diseases with synthetic peptides. Curr Protein Pept Sci. 2003;4(4):299-308.

30. Gonzalez L, Boyle RW, Zhang M, Castillo J, Whittier S, Della-Latta P, et al. Synthetic-peptide-based enzyme-linked immunosorbent assay for screening human serum or plasma for antibodies to human immunodeficiency virus type 1 and type 2. Clin Diagn Lab Immunol. 1997:4(5):598-603.

31. Sacks $D$, Noben-Trauth $N$. The immunology of susceptibility and resistance to Leishmania major in mice. Nat Rev Immunol. 2002;2(11):845-58.

32. Melby PC. Vaccination against cutaneous leishmaniasis: current status. Am J Clin Dermatol. 2002;3(8):557-70

33. Schijns VE, Lavelle EC. Trends in vaccine adjuvants. Expet Rev Vaccine. 2011;10(4):539-50

34. Allison AG, Gregoriadis G. Liposomes as immunological adjuvants. Nature. 1974;252(5480):252.

35. Uemura K, Nicolotti RA, Six HR, Kinsky SC. Antibody formation in response to liposomal model membranes sensitized with $\mathrm{N}$-substituted phosphatidylethanolamine derivatives. Biochemistry. 1974;13(8):1572-8.

36. Garcon NM, Six HR. Universal vaccine carrier. Liposomes that provide Tdependent help to weak antigens. J Immunol. 1991;146(11):3697-702.
37. Watson DS, Endsley AN, Huang L. Design considerations for liposoma vaccines: influence of formulation parameters on antibody and cellmediated immune responses to liposome associated antigens. Vaccine. 2012;30(13):2256-72.

38. Belkaid Y, Piccirillo CA, Mendez S, Shevach EM, Sacks DL. CD4 + CD25+ regulatory $T$ cells control Leishmania major persistence and immunity. Nature. 2002;420(6915):502-7.

39. Baylor NW, Egan W, Richman P. Aluminum salts in vaccines-US perspective. Vaccine. 2002;20 Suppl 3:S18-23.

40. Frazer $\mathbf{I H}$, Levin MJ. Paradigm shifting vaccines: prophylactic vaccines against latent varicella-zoster virus infection and against HPV-associated cancer. Current opinion in virology. 2011;1(4):268-79.

41. Hogenesch $\mathrm{H}$. Mechanism of immunopotentiation and safety of aluminum adjuvants. Front Immunol. 2012;3:406.

42. Aimanianda V, Haensler J, Lacroix-Desmazes S, Kaveri SV, Bayry J. Novel cellular and molecular mechanisms of induction of immune responses by aluminum adjuvants. Trends Pharmacol Sci. 2009:30(6):287-95.

43. Marrack P, McKee AS, Munks MW. Towards an understanding of the adjuvant action of aluminium. Nat Rev Immunol. 2009;9(4):287-93.

44. Kool M, Fierens K, Lambrecht BN. Alum adjuvant: some of the tricks of the oldest adjuvant. J Med Microbiol. 2012;61 (Pt 7):927-34.

45. MacLennan IC, Toellner KM, Cunningham AF, Serre K, Sze DM, Zuniga E, et al. Extrafollicular antibody responses. Immunol Rev. 2003;194:8-18.

46. Robinson HL, Amara RR. T cell vaccines for microbial infections. Nat Med. 2005;11(4 Suppl):S25-32.

47. Gregoriadis G. Immunological adjuvants: a role for liposomes. Immuno Today. 1990;11(3):89-97.

\section{Submit your next manuscript to BioMed Central and take full advantage of:}

- Convenient online submission

- Thorough peer review

- No space constraints or color figure charges

- Immediate publication on acceptance

- Inclusion in PubMed, CAS, Scopus and Google Scholar

- Research which is freely available for redistribution 